\title{
AN EMPIRICAL INVESTIGATION OF ENTREPRENEURIAL ORIENTATION OF WOMEN ENTREPRENEURS IN SABAH
}

\author{
Azlin Shafinaz Arshad ${ }^{*}$, Afiza Azura Arshad ${ }^{2}$, Laila Mohammad Kamaruddin ${ }^{3}$, \\ Siti Zahrah Buyong, ${ }^{4}$ Che Asniza Osman ${ }^{5}$ \\ 1,2,3,4 Malaysian Academy of SME \& Entrepreneurship Development (MASMED), \\ Universiti Teknologi MARA Selangor, Malaysia \\ 1,2,3,4,5 Faculty of Business and Management, Universiti Teknologi MARA Selangor, \\ Malaysia
}

*Corresponding Author email: azlinshafinaz@uitm.edu.my

\begin{abstract}
Entrepreneurial orientation has been recognized as one of the determinants of business performance. The purpose of this study is to determine the entrepreneurial orientation of women entrepreneurs in Sabah by adopting entrepreneurial orientation five-dimensions (innovativeness, proactiveness, risk-taking, competitive aggressiveness, and autonomy). A quantitative study using a questionnaire was adopted. The respondents of the study were women entrepreneurs who took part in Sabah Women Entrepreneur Carnival 2020 organized by Sabah Women's Affairs Department. The sampling method adopted was convenience sampling. Questionnaires were distributed to 150 women entrepreneurs but only 93 responses were usable. The findings of the study indicated women entrepreneurs in Sabah were entrepreneurial oriented as the mean scores were all above 3.5. Moreover, out of the five dimensions, the women entrepreneurs were more competitive as it has the highest mean score $(M=4.18)$. However, women entrepreneurs in Sabah were low on proactiveness since the mean score generated was the lowest among all five dimensions with $M=3.22$. The study adds some contributions to the field of entrepreneurship. Ministries and agencies involved with the development of women entrepreneurs in Sabah can aid and support women entrepreneurs to grow and sustain their business. Various courses and training can be offered to enhance women entrepreneur's knowledge and skills
\end{abstract}

Article History

Submission: July 27,2020

Revised: August 30, 2020

Accepted: September 24, 2020

Keywords:

Entrepreneurial

Orientation

Innovativeness,

Proactiveness, Risk-

Taking, Competitive

Aggressiveness,

Autonomy and Women

Entrepreneur

Abbreviations: NIL

\section{do}

10.31580/jmi.v7i3.1587

\section{INTRODUCTION}

Entrepreneurs are seen as catalyst agents in promoting economic activities as they are the ones who introduce new products and services, making improvements, and providing job opportunities (Ogunlana, 2018). Brush and Greene (2016) stated that entrepreneurship among women is acknowledged as the main contributor to the economic growth and societal well-being of many nations. Guled and Kaplan (2018) reported the fastest-growing entrepreneurial population today are women entrepreneurs. The role of women today has changed tremendously from the traditional role of being breadwinners and at the same time making an impact in society. In this regard, Sarfaraz, Faghih and Majd (2014) described today's women as playing a bigger role in the development of a country's economy. This is supported by Kamaruddin, Arshad, Osman, \& Buyong (2018) who opined that the contribution of women towards a country's development and growth is undeniable. Aliyu, Ahmad

\section{Readers /nsight}


and Nordin (2019) further emphasized women entrepreneurs' contribution towards their families, communities, and countries as huge. Arham, Norizan, Muslim and Aksan (2020) found there were no significant differences between males and females regarding their entrepreneurial orientation.

In today's world, women are no longer restricted to live their life in a traditional way. Many women today are now getting themselves busy with doing some business (Kamaruddin et al., 2018). Sarker and Palit (2014) described women entrepreneurs as people who create and grow business with high determination, hard-working, innovative, proactive, and persistence. Women entrepreneurs head and lead business they created with their own initiative (Ademokun \& Ajayi, 2012). Females who establish and manage business ventures are women entrepreneurs (Goyal and Parkash, 2011). Zapalska and Brozik (2014) defined women entrepreneurs as women who make a business decision on their business operation. Women entrepreneurs refer to women who own 51\% of the equity or holds the Chief Executive Officer (CEO) or Managing Director (MD) position and own at least $10 \%$ of the equity (SME Corp, 2016). Global Entrepreneurship Monitor (GEM, 2017) Women's Report stated that approximately 163 million women were becoming entrepreneurs around the world with 111 million estimated as already established businesses. Kamaruddin et al., (2018) emphasized that an increasing number of women are found in businesses owing to the changing role of women lately. This is supported by data from Economic Census 2016 - Profile of Small and Medium Enterprise (Malaysia 2017) where women who own business have increased to $20.7 \%$ from $19.7 \%$.

As the number of women entrepreneurs increased dramatically, many studies are also focusing on this group of entrepreneurs. The majority of studies were more focused on entrepreneurial competencies (Suhaimi, Al Mamun, Zainol, \& Nawi, 2018; Tehseen, Ahmed, Qureshi, Uddin \& Ramayah, 2019; Ahmad, Suseno, Seet, Susomrith, \& Rashid, 2018), motivation factors (Meliou \& Edwards, 2018; Bui, Kuan \& Chu, 2018), success factors (Ghouse, McElwee \& Durrah, 2019; Gupta \& Mirchandani, 2018) and challenges and barriers (Panda, 2018; Xie \& Lv 2018). According to Covin and Wales (2018), the number of research interests towards entrepreneurial orientation has increased dramatically. These studies on entrepreneurial orientation however are largely targeted at Small and Medium Enterprises (SMEs) and adopt Covin and Slevin's (1989) entrepreneurial orientation three-dimensional. Although there are many studies conducted on entrepreneurial orientation, the issue being debated by researchers are entrepreneurial orientation can be uni-dimensional or multidimensional. Therefore, this study is filling the gap by focusing on women entrepreneurs in Sabah and adopts entrepreneurial orientation five-dimensional as suggested by Lumpkin \& Dess (1996). This paper is structured as follows; literature review followed by methodology, findings, and finally the conclusion. 


\section{LITERATURE REVIEW}

Lumpkin and Dess (1996) described entrepreneurial orientation as processes, practices, and decision-making activities adopted by entrepreneurs which lead to the establishment of a firm. Entrepreneurial orientation is said to provide a solid foundation in assisting businesses to be more entrepreneurial and to act strategically (Hossain \& Al Asheq, 2019). Entrepreneurial orientation refers to the pattern of entrepreneurs' behaviors of a firm (Irwin, Landay, Aaron, McDowell, Marino \& Geho, 2018). Covin and Wales (2012) defined entrepreneurial orientation as relates to a firm's decision-making in engaging new, innovative, and entrepreneurial activities. Perez-Luno, Wiklund and Cabrera (2011) on the other hand state entrepreneurial orientation reflects the planning, analyzing, and decision-making process which reflects by the firm's culture, values, and its mission. To Nasip, Fabeil, Buncha, Hui, Sondoh \& Abd Halim (2017), entrepreneurial orientation is related to the strategymaking process that is reflected by the entrepreneurial firm. Arshad (2016) stated entrepreneurial orientation is the process, methods, and styles of Chief Executive Officers (CEOs) or top managers in managing their business operations and activities. Entrepreneurial orientation drives how a business pursues its entrepreneurial endeavors and activities (Covin \& Wales, 2012). The dimensions adopted for this study are based on the concept developed by Lumpkin and Dess (1996). These dimensions are elaborated in Table 1.

Table 1: Entrepreneurial orientation dimensions

\begin{tabular}{|c|c|}
\hline Dimensions & Descriptions \\
\hline Innovative & $\begin{array}{l}\text { A willingness to introduce innovation and novelty through experimentation and } \\
\text { creative processes aimed at developing new products and services, as well as new } \\
\text { processes. }\end{array}$ \\
\hline Proactiveness & $\begin{array}{l}\text { A forward-looking perspective characteristic of a marketplace leader that has the } \\
\text { foresight to seize opportunities in anticipation of future demand. }\end{array}$ \\
\hline Risk-taking & $\begin{array}{l}\text { Making decisions and taking actions without certain knowledge of probable } \\
\text { outcomes; some undertakings may also involve making substantial resource } \\
\text { commitments in the process of venturing forward. }\end{array}$ \\
\hline Com 1 & An intense effort to outperform industry rivals. It is characte \\
\hline ness & $\begin{array}{l}\text { posture or an aggressive response aimed at improving position or overcoming a } \\
\text { threat in a competitive marketplace. }\end{array}$ \\
\hline Autonomy & $\begin{array}{l}\text { Independent action by an individual or team aimed at bringing forth a business } \\
\text { concept or vision and carrying it through to completion. }\end{array}$ \\
\hline
\end{tabular}

Source: Lumpkin and Dess (1996)

\section{RESEARCH METHODOLOGY}

The approach that is adopted by the researcher for this study is a quantitative approach where the respondents were the owner, founder, and manager of the business. The sampling method used in the study was convenience sampling. The distribution of the survey questionnaire took place on 7th March 2020 and was distributed to a group of women entrepreneurs at Sabah Women Entrepreneur Carnival 2020 in Kota Kinabalu, Sabah. A total of 150 questionnaires were distributed 
to Sabah women entrepreneurs during the event and 118 were returned but only 93 questionnaires were deemed usable for further analysis. The survey questionnaires were taken from Lumpkin and Dess (1996) which uses five dimensions of entrepreneurial orientation; innovativeness, proactiveness, risk-taking, competitive aggressiveness, and autonomy. The survey questionnaires were divided into two sections. The first part was questioned on respondents' backgrounds and their business. The second part was questions related to entrepreneurial orientation dimensions (innovation, proactiveness, risk-taking, competitive aggressiveness, and autonomy) with eighteen items which were measured on 5-points scale. In analyzing the data, analysis of descriptive analyses using mean and standard deviation, reliability test using Cronbach Alpha, and normality test using skewness and kurtosis were conducted using Statistical Package for Social Science (SPSS) version 26.

\section{FINDINGS AND ANALYSIS}

The survey questionnaires were distributed during the Sabah Women Entrepreneur Carnival 2020 that took place in Kota Kinabalu, Sabah. The summary of the respondent is presented in Table 2. From a total of 93 usable responses, the study found that the majority of women entrepreneurs that took part in the survey are above 40 years old with 43 percent, followed by 23.7 percent for respondents between the age of 35-39 years old. Only 2.2 percent is below 24 years old. Respondents who are married contributed to the highest percentage with 66.7 percent, single with 19.4 percent, divorced 7.5 percent, and separated 6.5 percent. Many of the women entrepreneurs had their Sijil Pelajaran Malaysia (SPM) qualification for the academic background where the percentage is almost half of the respondents (48\%) followed with Diploma graduates (23.7\%) and Bachelor's Degree (15.1\%). Women entrepreneurs that have postgraduate qualification were at 5.4 percent and completed with the primary school was at 2.2 percent. For the business sector, the majority are in the food and beverages (31.2\%), service (28\%), and manufacturing $(25.8 \%)$. The least business sector that women entrepreneurs involved in is apparel $(9.7 \%)$ and agriculture $(5.4 \%)$. The majority of women entrepreneurs have been operating their business between one to five years $(52.7 \%)$ and registered their business as a sole proprietorship (77.4\%). Many of these businesses were located in the Kota Kinabalu $(62.4 \%)$ while only $41.6 \%$ are out of Kota Kinabalu such as Keningau, Tawau, Kudat, and many major towns. Most of the respondents stated that they have less than 5 workers in their business which indicates that they are micro-businesses and not even Small and Medium Enterprises (SMEs).

Table 2: Profile of respondents

\begin{tabular}{llcc}
\hline Description & & Frequency & Percentage \\
\hline Age & Below 24 & 2 & 2.2 \\
& $24-29$ & 15 & 16.1 \\
& $30-34$ & 14 & 15.1 \\
& $35-39$ & 22 & 23.7 \\
\hline
\end{tabular}




\begin{tabular}{|c|c|c|c|}
\hline Description & & Frequency & Percentage \\
\hline & Above 40 & 40 & 43 \\
\hline \multirow[t]{4}{*}{ Marital Status } & Single & 18 & 19.4 \\
\hline & Married & 62 & 66.7 \\
\hline & Separated & 6 & 6.5 \\
\hline & Divorced & 7 & 7.5 \\
\hline \multirow[t]{7}{*}{ Academic background } & Primary & 2 & 2.2 \\
\hline & Secondary & 45 & 48.4 \\
\hline & Certificate & 5 & 5.4 \\
\hline & Diploma & 22 & 23.7 \\
\hline & Bachelor Degree & 14 & 15.1 \\
\hline & Masters & 4 & 4.3 \\
\hline & $\mathrm{PhD}$ & 1 & 1.1 \\
\hline \multirow[t]{5}{*}{ Business Sector } & Manufacturing & 24 & 25.8 \\
\hline & Service & 26 & 28 \\
\hline & Agriculture & 5 & 5.4 \\
\hline & Apparel & 9 & 9.7 \\
\hline & Food \& Beverages & 29 & 31.2 \\
\hline \multirow[t]{4}{*}{ Years of Establishment } & Less than 1 & 24 & 25.8 \\
\hline & $1-5$ & 49 & 52.7 \\
\hline & $6-10$ & 14 & 15.1 \\
\hline & More than 10 & 6 & 6.5 \\
\hline \multirow[t]{3}{*}{ Form of business } & Sole proprietorship & 72 & 77.4 \\
\hline & Partnership & 13 & 14 \\
\hline & Private Limited & 8 & 8.6 \\
\hline \multirow[t]{14}{*}{ Location } & Kota Kinabalu & 58 & 62.4 \\
\hline & Tawau & 4 & 4.3 \\
\hline & Sandakan & 1 & 1.1 \\
\hline & Lahad Datu & 1 & 1.1 \\
\hline & Kinabantangan & 2 & 2.2 \\
\hline & Keningau & 5 & 5.4 \\
\hline & Papar & 2 & 2.2 \\
\hline & Penampang & 2 & 2.2 \\
\hline & Ranau & 1 & 1.1 \\
\hline & Tuaran & 3 & 3.2 \\
\hline & Kudat & 4 & 4.3 \\
\hline & Beaufort & 2 & 2.2 \\
\hline & Tenom & 3 & 3.2 \\
\hline & Others & 5 & 5.4 \\
\hline \multirow[t]{4}{*}{ Number of workers } & Less than 5 & 73 & 77.4 \\
\hline & $5-30$ & 19 & 14 \\
\hline & $31-74$ & 0 & 0 \\
\hline & 75 and above & 1 & 8.6 \\
\hline
\end{tabular}

The results of the reliability test are shown in Table 3. The Cronbach Alpha values show all the measures are greater than 0.6 which indicates that the variables were internally consistent, and the scales deemed reliable for further analyses (Hair, Black, Babin, Anderson \& Tatham, 2006). 
Table 3: Reliability test results

\begin{tabular}{lcc}
\hline Measures & Number of Items & Cronbach Alpha \\
\hline Innovativeness & 3 & 0.609 \\
Proactiveness & 3 & 0.654 \\
Risk-taking & 3 & 0.805 \\
Competitive Aggressiveness & 3 & 0.855 \\
Autonomy & 4 & 0.748 \\
\hline
\end{tabular}

The analysis conducted in the study is a descriptive analysis and normality test. Descriptive analysis was performed to describe the basic features of the data collected for the study using mean and standard deviation. In addition, normality test was also conducted. Skewness and kurtosis were performed to determine if indicators met normality assumptions (Kline, 2005). The mean scores for innovativeness as shown in Table 4 is between 3.96 to 4.03 . The highest mean indicated by the women entrepreneurs favors experimentation and original approaches to problem-solving $(\mathrm{M}$ $=4.03$ ) followed with strongly emphasized on research and development (R\&D), technological leadership, and innovations $(M=3.98)$ and have marketed many new lines of products or services $(M=3.96)$. The skewness score for all items is negative skewed while the kurtosis values are all items are positive. Hence, it indicates all items are normally distributed as skewness and kurtosis values are within the acceptable range of \pm 2 (George \& Mallory, 2016).

Table 4: Mean Scores for Innovativeness

\begin{tabular}{lcccc}
\hline Items & Mean & Std. Dev. & Skewness & Kurtosis \\
\hline $\begin{array}{l}\text { Strongly emphasis on research and development (R\&D), } \\
\text { technological leadership, and innovations }\end{array}$ & 3.98 & .847 & -.947 & 1.806 \\
$\begin{array}{l}\text { Have marketed many new lines of products or services } \\
\text { Favours experimentation and original approaches to }\end{array}$ & 3.96 & .802 & -.515 & .731 \\
problem-solving & 4.03 & .786 & -.879 & 1.680 \\
\hline
\end{tabular}

For proactiveness, the mean for all three items in the range of 3.22 to 3.90. The highest mean was generated for item "Prefers to design own processes and methods of production and techniques rather than adapting what others have developed and proven" (M=3.90) while the lowest mean was for item "Prefer to undo the competitors" (M=3.22). All items are normally distributed as skewness and kurtosis values are within the acceptable range of \pm 1.5 (Tabachnick \& Fidell, 2013). All of the results are depicted in Table 5.

Table 5: Mean Scores for Proactiveness

\begin{tabular}{llcccc}
\hline Items & Mean & Std. Dev. & Skewness & Kurtosis \\
\hline $\begin{array}{l}\text { Prefers to design own processes and methods of } \\
\text { production and techniques rather than adapting what } \\
\text { others have developed and proven }\end{array}$ & & & & .90 \\
$\begin{array}{l}\text { Introduce new products/services, administrative } \\
\text { techniques, and operating technologies }\end{array}$ & 3.81 & 0.968 & -.906 & .627 \\
Prefer to undo the competitors & 3.22 & 1.150 & -1.008 & 1.227 \\
\hline
\end{tabular}


Results for risk-taking are presented in Table 6. The study discovered that the mean ranges from 3.88 to 4.14 . The highest mean is found in the statement "Adopts bold, aggressive posture to maximize the probability of exploiting potential opportunities with mean scores of 4.14 followed with "Owing to the nature of the environment, it is best to explore the environment boldly with wide-ranging acts necessary to achieve firm objectives" with mean score of 4.01 and Strong proclivity on risky projects with mean score of 3.88. All items are assumed to be normal for skewness and kurtosis as the values are within the range of \pm 2 (George \& Mallory, 2016).

Table 6: Mean Scores for Risk-taking

\begin{tabular}{|c|c|c|c|c|}
\hline Items & Mean & Std. Dev. & Skewness & Kurtosis \\
\hline Strong proclivity for risky projects & 3.88 & 0.883 & -1.024 & 1.503 \\
\hline $\begin{array}{l}\text { Owing to the nature of the environment, it is best to } \\
\text { explore the environment boldly with wide-ranging acts } \\
\text { necessary to achieve firm objectives }\end{array}$ & 4.01 & 0.903 & -.746 & .341 \\
\hline $\begin{array}{l}\text { Adopts bold, aggressive posture to maximize the } \\
\text { probability of exploiting potential opportunities }\end{array}$ & 4.14 & 0.892 & -1.033 & .993 \\
\hline
\end{tabular}

Items for competitive aggressiveness were all above mean values of 3.5 and presented in Table 7. The highest mean was the item "Be aggressive and intensively competitive" (M=4.00) followed by "Most likely initiate actions that competitors will respond to" $(\mathrm{M}=3.97)$ and "Uses unconventional strategies to challenge competitors $(\mathrm{M}=3.90)$. All items for proactiveness has negative skewness score and positive kurtosis values respectively. Hence, all items are normally distributed as skewness and kurtosis values are within the range of \pm 2 (George \& Mallory, 2016).

Table 7: Mean Scores for Competitive Aggressiveness

\begin{tabular}{lcccc}
\hline Items & Mean & Std. Dev. & Skewness & Kurtosis \\
\hline Most likely initiate actions that competitors will respond to & 3.97 & 0.827 & -1.000 & 2.162 \\
Be aggressive and intensively competitive & 4.00 & 0.847 & -.658 & .552 \\
Uses unconventional strategies to challenge competitors & 3.90 & 0.861 & -.438 & .103 \\
\hline
\end{tabular}

The mean scores for the final dimensions of entrepreneurial orientation, autonomy is demonstrated in Table 8. The mean scores ranging between 3.58 to 4.18. Two items that have a mean score of above 4 are items "Plays a major role in identifying and selecting the entrepreneurial opportunities to pursue new market" and "Believes best results occur when individuals and teams provide primary impetus for pursuing business opportunities" ( $M=4.18 ; M=4.10)$ respectively. The other two items with mean scores above 3.5 are "Prefers working autonomously with no reliance on teamwork and guidance from others" (M=3.99) and "Pursues business opportunities without obtaining approval from others" $(\mathrm{M}=3.58)$. All items are normally distributed as skewness and kurtosis values are within the range of \pm 3 (Othman Talib, 2013). 
Table 8: Mean Scores for Autonomy

\begin{tabular}{llcccc}
\hline Items & Mean & Std. Dev. & Skewness & Kurtosis \\
\hline $\begin{array}{l}\text { Prefers working autonomously with no reliance on } \\
\text { teamwork and guidance from others }\end{array}$ & 3.99 & 0.915 & -.849 & .518 \\
$\begin{array}{l}\text { Believes best results occur when individuals and teams } \\
\text { provide primary impetus for pursuing business }\end{array}$ & 4.10 & 0.781 & -1.151 & 2.540 \\
$\begin{array}{l}\text { opportunities } \\
\begin{array}{l}\text { Pursues business opportunities without obtaining } \\
\text { approval from others }\end{array}\end{array}$ & & & & \\
$\begin{array}{l}\text { Plays a major role in identifying and selecting the } \\
\text { entrepreneurial opportunities to pursue new market }\end{array}$ & 4.18 & 0.751 & -1.102 & 2.706 \\
\hline
\end{tabular}

This study adopts entrepreneurial orientation five-dimensional as suggested by Lumpkin \& Dess (1996). The highest mean score is represented by competitive aggressiveness $(M=3.9624)$ while the lowest mean score is represented by proactiveness $(M=3.6909)$. Findings of the study elucidated that women entrepreneurs in Sabah are entrepreneurial oriented as all the mean scores were above 3.5. Interestingly, the study found that these women entrepreneurs in Sabah are very competitive as the mean scores generate higher mean scores compared to other entrepreneurial orientation dimensions. However, the study found women entrepreneurs in Sabah are less proactive as it showed the lowest mean scores. The mean scores for each dimension of entrepreneurial orientation are depicted in Table 9.

Table 9: Mean Scores for Entrepreneurial Orientation Dimension

\begin{tabular}{lcccc}
\hline Items & Mean & Standard Deviation & Skewness & Kurtosis \\
\hline Innovativeness & 3.9570 & .608 & -.419 & .253 \\
Proactiveness & 3.6909 & .684 & -.488 & .392 \\
Risk-Taking & 3.8928 & .772 & -1.093 & 2.050 \\
Competitive Aggressiveness & 3.9624 & .774 & -.542 & 1.347 \\
Autonomy & 3.9570 & .692 & -.979 & 2.907 \\
\hline
\end{tabular}

\section{CONCLUSION}

The study aims to determine the entrepreneurial orientation of women entrepreneurs in Sabah by adopting all five dimensions of entrepreneurial orientation. The study found that women entrepreneurs in Sabah were all entrepreneurial oriented as the mean scores for each dimension are above 3.5. The highest mean scores for innovativeness item is $M=4.03$, favours experimentation and original approaches to problem-solving; proactiveness items is $\mathrm{M}=3.90$, prefers to design own processes and methods of production and techniques rather than adapting what others have developed and proven; risk-taking items are $\mathrm{M}=4.14$, adopts bold, aggressive posture to maximize the probability of exploiting potential opportunities, competitive aggressiveness items is $\mathrm{M}=4.00$, be aggressive and intensively competitive and last dimension autonomy is $\mathrm{M}=4.18$, plays a major role in identifying and selecting the entrepreneurial opportunities to pursue the new market. As for each dimension of 
entrepreneurial orientation, competitive aggressiveness was found to be the most favoured by Sabah women entrepreneurs since it holds the highest mean of 3.9624 while the least favoured is proactive with mean score of 3.6909 .

By researching the entrepreneurial orientation of women entrepreneurs, this study gives significant values to the entrepreneurship literature. The findings of the present study may spark the interest of researchers, government agencies, and policymakers. In addition, the results of the study can provide some directions and insight to the local government and related agencies on courses and training to be given to women entrepreneurs to increase the proactiveness of women entrepreneurs in Sabah. Though this study gives very insightful information about the entrepreneurial orientation of women entrepreneurs in Sabah, there are some limitations. The sample of the study is small although the respondent comes from various districts in Sabah. As the study adopts a quantitative approach, the study could not investigate further on the results obtained for instance the reason why proactiveness has the lowest scores. To enhance further the study, it is recommended that future studies conduct a qualitative study to have a deeper understanding of entrepreneurial orientation of Sabah women entrepreneurs. Another aspect to be considered for a future researcher is to conduct a similar study on male entrepreneurs to see if the result differs.

\section{Acknowledgements}

The study is supported by the University of Technology MARA under LESTARI Research Grant 2019 (600-IRMI/Dana KCM 5/3/LESTARI (036/2018) entitled Factors Affecting the Performance of Women Entrepreneurs in Sabah.

\section{Reference:}

Ademokun, F., \& Ajayi, O. (2012). Entrepreneurship development, business ownership and women empowerment in Nigeria. Journal of Business Diversity, 12(1), 72-87.

Ahmad, N.H., Suseno, Y., Seet, P.S., Susomrith, P., \& Rashid, Z. (2018). Entrepreneurial competencies and firm performance in emerging economies: A study of women entrepreneurs in Malaysia. In Knowledge, learning and innovation (pp. 5-26). Springer, Cham.

Aliyu, R. M., Ahmad, T. S. B. T., \& Nordin, N. B. (2019). The Mediating Role of Innovation on Access to Finance and Business Performance of Women Entrepreneurs. International Journal of Academic Research in Business and Social Sciences, 9(3), 147-159.

Arham, A. F., Norizan, N. S., Muslim, N. H., \& Aksan, A. (2020). Effects of Gender on Leadership, Entrepreneurial Orientation and Organisational Performance. Social and Management Research Journal, 17(1), 49-60.

Arshad, A.S. (2016). Leadership Styles, Entrepreneurial Orientation and Business Performance of Technology-based Small Medium Enterprises in Malaysia. Doctor of Philosophy (Management), Universiti Teknologi Malaysia (UTM), Malaysia.

Brush, C.G., \& Greene, P.G. (2016). Closing the Gender Gap in Entrepreneurship: A New Perspective on Policies and Practices. Organization for Economic Cooperation and Development.

Bui, H.T., Kuan, A., \& Chu, T.T. (2018). Female entrepreneurship in patriarchal society: motivation and challenges. Journal of Small Business \& Entrepreneurship, 30(4), 325-343.

Covin, I. G., \& Slevin, D. P. (1989). Strategic management of small firms in hostile and benign environments. Strategic Management Journal, 10(1), 75-87 
Covin, J.G., \& Wales, W.J. (2018). Crafting High-Impact Entrepreneurial Orientation Research: Some Suggested Guidelines. Entrepreneurship Theory and Practice. Entrepreneurship Theory and Practice, 43(1), 3-18.

Covin, J.G., \& Wales, W.J. (2012). The measurement of entrepreneurial orientation. Entrepreneurship Theory and Practice, 36(4), 677-702.

George, D., \& Mallery, P. (2016). IBM SPSS Statistics 23 Step by Step: A Simple Guide and Reference (13th ed.). New York: Routledge.

Ghouse, S.M., McElwee, G., \& Durrah, O. (2019). Entrepreneurial success of cottage-based women entrepreneurs in Oman. International Journal of Entrepreneurial Behavior \& Research, 25(3), 480-498.

Goyal, M., \& Parkash, J. (2011). Women entrepreneurship in India-problems and prospects. International Journal of Multidisciplinary Research, 1(5), 195-207.

Guled, N.S., \& Kaplan, B. (2018). Factors Influencing Women Entrepreneurs' Business Success in Somalia. Research in Business and Management, 5(1), 13-24.

Gupta, N., \& Mirchandani, A. (2018). Investigating entrepreneurial success factors of women-owned SMEs in UAE. Management Decision, 56(1), 219-232.

Hair, J. F., Black, W. C., Babin, B. J., Anderson, R. E., \& Tatham, R. L. (2006). Multivariate data analysis 6th Edition. Pearson Prentice Hall. New Jersey. humans: Critique and reformulation. Journal of Abnormal Psychology, 87, 49-74.

Hossain, M. U., \& Al Asheq, A. (2019). The Role of Entrepreneurial Orientation to SME Performance in Bangladesh. International Journal of Entrepreneurship, 23(1), 1-6.

Irwin, K.C., Landay, K.M., Aaron, J.R., McDowell, W.C., Marino, L.D., \& Geho, P.R. (2018). Entrepreneurial orientation (EO) and human resources outsourcing (HRO): A "HERO" combination for SME performance. Journal of Business Research, 90, 134-140.

Kamaruddin, L.M., Arshad, A.S., Osman, C.A. \& Buyong, S.Z. (2018). An Exploratory Study of Malaysian Women Entrepreneurs: What Drives Them into Business, ASEAN Entrepreneurship Journal, 4(2), 84-96.

Kline, R. B. (2005). Methodology in the social sciences.

Lumpkin, G.T., \& Dess, G.G. (1996). Clarifying the entrepreneurial orientation construct and linking it to performance. Academy of Management Review, 21(1), 135-172.

Malaysia (2017). Economic Census 2016: Profile of Small and Medium Enterprises. Putrajaya: Department of Statistics.

Meliou, E., \& Edwards, T. (2018). Relational practices and reflexivity: Exploring the responses of women entrepreneurs to changing household dynamics. International Small Business Journal, 36(2), 149-168.

Monitor, G.E. (2017). Women's Entrepreneurship 2016/2017 Report.

Nasip, S., Fabeil, N.F., Buncha, M.R., Hui, J.N.L., Sondoh, S.L., \& Abd Halim, D.N. (2017). Influence of entrepreneurial orientation and social capital on business performance among women entrepreneurs along west coast Sabah Malaysia. In Proceedings of International Conference on Economics (pp. 377-393).

Ogunlana, F. (2018). The Role of Entrepreneurship as the Driver of Economic Growth.

Othman Talib. (2013). Asas penulisan tesis penyelidikan dan statistik. Serdang: Universiti Putra Malaysia.

Panda, S. (2018). Constraints faced by women entrepreneurs in developing countries: review and ranking. Gender in Management: An International Journal, 33(4), 315-331. 
Pérez-Luño, A., Wiklund, J., \& Cabrera, R. V. (2011). The dual nature of innovative activity: How entrepreneurial orientation influences innovation generation and adoption. Journal of Business Venturing, 26(5), 555-571.

Sarfaraz, L., Faghih, N. \& Majd, A.A. (2014). The relationship between women entrepreneurship and gender equality. Journal of Global Entrepreneurship Research, 2(1), 1-11.

Sarker, S., \& Palit, M. (2014). Determinants of success factors of women entrepreneurs in BangladeshA study based on Khulna region. Business and Economic Research, 4(2), 237.

SME Corp (2016). SME Annual Report 2016/2016. Retrieved 5 December 2016 from http://www.smecorp.gov.my/index.php/en/sme-annual-report-2015-16.

Suhaimi, N.H.B.M., Al Mamun, A., Zainol, N.R., \& Nawi, N. (2018). The moderating effect of a supportive environment toward the relationship of entrepreneurial competencies and the performance of informal women entrepreneurs in Kelantan, Malaysia. The Journal of Developing Areas, 52(1), 251-259.

Tabachnick, B.G. \& Fidell, L.S. (2013). Using Multivariate Statistics, Upper Saddle River.

Tehseen, S., Ahmed, F.U., Qureshi, Z.H., Uddin, M.J., \& Ramayah, T. (2019). Entrepreneurial competencies and SMEs' growth: the mediating role of network competence. Asia-Pacific Journal of Business Administration 11(1), 2-29.

Xie, X., \& Lv, J. (2018). Female technology entrepreneurs: resource shortages and reputation challengesa view of institutional support. International Entrepreneurship and Management Journal, 14(2), 379-403.

Zapalska, A.M., \& Brozik, D. (2014). Female entrepreneurial businesses in tourism and hospitality industry in Poland. Management, 12(2), 7-13. 